\begin{tabular}{|c|c|c|c|c|}
\hline \multirow{2}{*}{ EXPORTS } & \multicolumn{2}{|c|}{1913} & \\
\hline & $\begin{array}{l}1000 \mathrm{lb} . \\
\text { units }\end{array}$ & $\underset{\text { units }}{\$ 1000}$ & $\begin{array}{l}10001 \mathrm{~b} . \\
\text { units }\end{array}$ & $\begin{array}{l}\$ 1000 \\
\text { units }\end{array}$ \\
\hline $\begin{array}{l}\text { lcium carbide. } \\
\text { lcium acetate. }\end{array}$ & $\begin{array}{l}32,362 \\
74,056\end{array}$ & $\begin{array}{r}946 \\
2,158\end{array}$ & $\begin{array}{l}32,750 \\
47,897\end{array}$ & $\begin{array}{l}989 \\
833\end{array}$ \\
\hline $\begin{array}{l}\text { pper sulfate..... } \\
\text { dium compound }\end{array}$ & $\begin{array}{r}7,050 \\
4,169\end{array}$ & 212 & 7,387 & 328 \\
\hline cids: & & & & \\
\hline Sulfuric... & 9,689 & 104 & 13,176 & 140 \\
\hline & Tons & & Tons & \\
\hline 1 fur, raw,... & 89 & 1,600 & 98 & 1,807 \\
\hline & $\begin{array}{c}1000 \text { gal } \\
\text { units }\end{array}$ & & $\begin{array}{c}1000 \text { gal. } \\
\text { units }\end{array}$ & \\
\hline $\begin{array}{l}\text { ethyl } \text { alcohol } 1, \\
\text { yes }\end{array}$ & 1,951 & 827 & 1,161 & $\begin{array}{r}479 \\
538\end{array}$ \\
\hline In bark extract & $\ldots \ldots$ & 508 & $\ldots$ & 1,084 \\
\hline & $\begin{array}{c}1000 \mathrm{lb} . \\
\text { units }\end{array}$ & & $\begin{array}{c}1000 \mathrm{lb} . \\
\text { units } \\
155\end{array}$ & \\
\hline $\begin{array}{l}\text { nseng.......................... } \\
\text { ots, herbs, barks, etc. }\end{array}$ & & $\begin{array}{r}1,480 \\
476\end{array}$ & & $\begin{array}{r}1,265 \\
410\end{array}$ \\
\hline ines notent and pron & & 6,966 & & 6,521 \\
\hline ikir & 2,956 & 866 & 2,858 & 779 \\
\hline $\begin{array}{l}\text { ashing powder, etc. } \\
\text { troleum jelly, vaseli }\end{array}$ & 11,224 & $\begin{array}{l}506 \\
635\end{array}$ & 12,683 & $\begin{array}{l}533 \\
640\end{array}$ \\
\hline AP AND TOILE & & & & \\
\hline Toilet soa & & 2,185 & & 1,801 \\
\hline Other soal & 55,528 & 2,672 & 59,514 & 2,863 \\
\hline $\begin{array}{l}\text { Perfumes al } \\
\text { Soap mater }\end{array}$ & & $\frac{1}{5}, 575$ & & $\begin{array}{l}1,514 \\
4,421\end{array}$ \\
\hline XPLOSIVES: & & & & \\
\hline & & 3,015 & & 6,5 \\
\hline & 13,310 & 1,498 & 11,303 & 1,214 \\
\hline $\begin{array}{l}\text { Gunpowd } \\
\text { Other ex }\end{array}$ & 1,284 & $\begin{array}{l}360 \\
652\end{array}$ & 867 & $\begin{array}{r}290 \\
1967\end{array}$ \\
\hline is, fixed and & & & & \\
\hline $\begin{array}{l}\text { Cot } \\
\text { Cor }\end{array}$ & $\begin{array}{r}264,779 \\
17,789\end{array}$ & $\begin{array}{r}17,991 \\
1,219\end{array}$ & $\begin{array}{r}216,309 \\
16,204\end{array}$ & $\begin{array}{r}14,684 \\
1,127\end{array}$ \\
\hline & $\begin{array}{c}1000 \text { gal. } \\
\text { units } \\
1.591\end{array}$ & & $\begin{array}{c}1000 \text { gal. } \\
\text { units } \\
266\end{array}$ & \\
\hline & & 418 & & 393 \\
\hline $\begin{array}{c}\text { Animal } \\
\text { Includ }\end{array}$ & $\begin{array}{l}2,507 \\
1,187\end{array}$ & $\begin{array}{l}1,250 \\
319\end{array}$ & $\begin{array}{l}871 \\
155\end{array}$ & 542 \\
\hline & & 102 & 102 & 81 \\
\hline Mine & & & & \\
\hline & 194,570 & 8,448 & 124,736 & $\begin{array}{r}4,959 \\
64\end{array}$ \\
\hline & & $\begin{array}{l}72,042 \\
29,609\end{array}$ & $\begin{array}{l}1,010,449 \\
191,648\end{array}$ & 64,113 \\
\hline & $\begin{array}{l}0.728 \\
, 728\end{array}$ & $\begin{array}{l}29,009 \\
17,419\end{array}$ & 162, & $\begin{array}{l}20,310 \\
19,898\end{array}$ \\
\hline & & 10,674 & 47,024 & 5,391 \\
\hline & & 9,991 & 634,297 & 18,019 \\
\hline & & 1,134 & & 1,205 \\
\hline Paraffin & 236,046 & 8,177 & 188,823 & 6,435 \\
\hline Ether & $\begin{array}{c}1000 \text { lh. } \\
\text { units }\end{array}$ & & $\begin{array}{c}1000 \mathrm{lb} . \\
\text { units }\end{array}$ & \\
\hline & 112 & 367 & & 309 \\
\hline & $1000 \mathrm{bbl}$ & 234 & & 229 \\
\hline $\begin{array}{l}\text { AVAL, STORES. } \\
\text { Rosin } \ldots \ldots \ldots \ldots \ldots \ldots \ldots \ldots \ldots \ldots \ldots \ldots\end{array}$ & $\begin{array}{l}\text { units } \\
2,605\end{array}$ & & $\begin{array}{c}\text { units } \\
1,749\end{array}$ & \\
\hline Tar turentine and pitc & & 526 & & 541 \\
\hline & $\begin{array}{c}1000 \text { gal. } \\
\text { units }\end{array}$ & & $\begin{array}{l}1000 \text { gal. } \\
\text { units }\end{array}$ & \\
\hline Turpentine oil. & 20,024 & 8,161 & 11,118 & 5,189 \\
\hline & $\begin{array}{c}1000 \text { ton } \\
\text { units }\end{array}$ & & $\begin{array}{l}1000 \text { ton } \\
\text { units }\end{array}$ & \\
\hline e hard rock. & & & 282 & \\
\hline & 891 & 5,255 & 681 & 3,9 \\
\hline & 73 & 1,667 & 64.1 & $1,5.5$ \\
\hline ISCE & & & & \\
\hline$\ldots \ldots \ldots \ldots$ & $\begin{array}{l}5,384 \\
882\end{array}$ & $\begin{array}{r}392 \\
3,310\end{array}$ & $\begin{array}{l}3,921 \\
592\end{array}$ & 2,237 \\
\hline & $\begin{array}{l}1000 \mathrm{lb} \text {. } \\
\text { units }\end{array}$ & & $\begin{array}{c}1000 \mathrm{1b} . \\
\text { units }\end{array}$ & \\
\hline $\begin{array}{l}\text { Mercury } \\
\text { Celluloid. }\end{array}$ & & $\begin{array}{r}44 \\
1,317\end{array}$ & & $\begin{array}{r}71 \\
1.109\end{array}$ \\
\hline & & & & \\
\hline $\begin{array}{l}\text { Waste } \\
\text { Reclair }\end{array}$ & $\begin{array}{l}6,560 \\
4,988\end{array}$ & $\begin{array}{l}768 \\
837\end{array}$ & $\begin{array}{l}4,187 \\
6,250\end{array}$ & $\begin{array}{l}409 \\
872\end{array}$ \\
\hline & $\begin{array}{c}1000 \text { ton } \\
\text { units }\end{array}$ & & $\begin{array}{c}1000 \text { ton } \\
\text { units }\end{array}$ & \\
\hline Wood flour. & & 738 & 11 & 484 \\
\hline & $\begin{array}{c}1000 \mathrm{lb} . \\
\text { units }\end{array}$ & & & \\
\hline & & 7,484 & & 2,926 \\
\hline & & 260 & 2,248 & 243 \\
\hline & & & & \\
\hline $\begin{array}{l}\text { Electric lamps: } \\
\text { Arc............ }\end{array}$ & $\begin{array}{l}\text { units } \\
7.7\end{array}$ & & $\begin{array}{l}\text { units } \\
2 \text {. }\end{array}$ & \\
\hline $\begin{array}{l}\text { Carbon filament } \\
\text { Metallic flament }\end{array}$ & $\begin{array}{l}1,844 \\
1,091\end{array}$ & $\begin{array}{l}255 \\
302\end{array}$ & $\begin{array}{r}608 \\
1,348\end{array}$ & $\begin{array}{r}88 \\
278\end{array}$ \\
\hline & $\underset{\text { feet }}{\text { Running }}$ & & $\underset{\text { feet }}{\text { Running }}$ & \\
\hline $\begin{array}{l}\text { Photographic films for cinemato } \\
\text { graph (unexposed) } \ldots \ldots \ldots \ldots \ldots \\
\text { Other sensitized products. } \ldots \ldots \ldots \ldots\end{array}$ & 114,124 & $\begin{array}{l}3,056 \\
2,107\end{array}$ & 88,401 & $\begin{array}{l}2,5 \\
1,4\end{array}$ \\
\hline & & 777 & & \\
\hline & $\begin{array}{c}1000 \text { bbl. } \\
\text { units } \\
2 \text { 964 }\end{array}$ & 271 & $\begin{array}{c}1000 \text { bbl. } \\
\text { units } \\
2,140\end{array}$ & $39-290>3$ \\
\hline
\end{tabular}

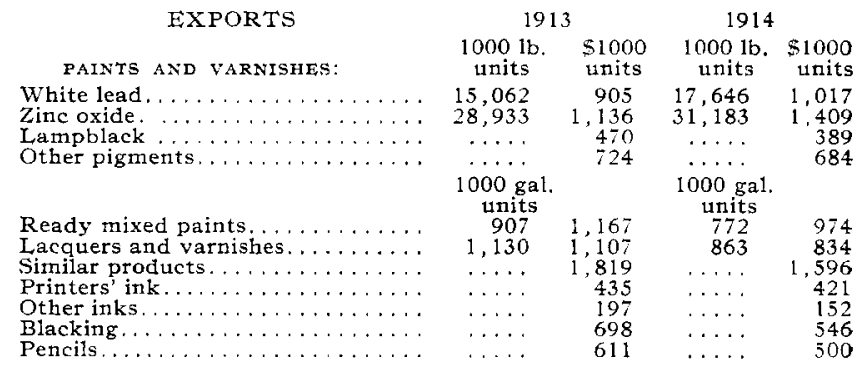

\section{THE GERMAN LEAD INDUSTRY}

A number of German works, members of the German Sales Bureau for Rolled and Pressed Lead Manufacturers, have, according to Engineering 99 (I9I5), 247, formed a combine under the name of the United Lead and Tin Works, Limited, Cologne, and have also entered into an agreement with the Rhenish-Nassau Mining Company, Stolberg. A central rollingmill will be erected in direct connection with the works. The new firm, after the erection of the central works, will remain a member of the above-mentioned sales bureau, an agreement. having been arrived at to this effect. The new company, however, will not only manufacture goods for the sales bureau, but also specialties, which the different works hitherto have manufactured for their own account. The Gelsenkirchen Lead Works, which is at present idle, will be extended and maintained as a kind of center for the coal district. The capital of the new company amounts to $3,150,000$ marks.

\section{A NEW TYPE OF OIL CARRIER, THE CYLINDRICAL TANK STEAMER "RICARDO A. MESTRES"}

A new type of oil-carrying steamer has recently been built in England; in it the oil, instead of being carried in ordinary holds with straight bulkheads, is contained in large vertical cylindrical tanks, so that there is a freedom from webs and stiffeners on the internal surface, the consequence being that the process of cleansing is greatly expedited and more effective. The tanks are of sufficient capacity to take the full dead-weight load of heavy oil, and ordinary cargo or light oil can be shipped in the spaces between the outer walls of the cylindrical tank and the sides of the ship, this space being divided up into a number of compartments by water-tight bulkheads.

A vessel of this type, the "Ricardo A. Mestres," is illustrated in a recent issue of Engineering; she was constructed for the Transcontinental Petroleum Company, and is the third of her type to be put into service.

This vessel has a length between perpendiculars of $365 \cdot \mathrm{ft}$., a breadth extreme of $50 \mathrm{ft} .9 \mathrm{in}$., and moulded of $50 \mathrm{ft} .6^{1 / 2} \mathrm{in}$., while the depth moulded is $29 \mathrm{ft} .3 \mathrm{int}$. She is built with a double bottom extending throughout the full length of the ship, with the usual fore peak, in which oil fuel may be carried in supplement to the oil fuel in the athwartship bunker immediately in front of the boiler compartment, which, with the engine-room, is placed in the after part of the ship. There are five tanks for the carrying of heavy oil. The forward tank has a capacity of $32,850 \mathrm{cu}$. ft., the other four of $38,025 \mathrm{cu}$. ft. each; the holdtanks, at the side of and between the cylindrical tanks, on the port as well as the starboard side, are of a capacity each of 10,642 cu. $\mathrm{ft}$. In addition, oil may be carried in the five double-bottom tanks, as marked on the longitudinal section; and these, including the accommodation of the expansion trunks formed in connection with the decks, make the total capacity of the cargo spaces up to $285,793 \mathrm{cu} . \mathrm{ft}$. Excluding the expansion trunks, the total capacity is $263,968 \mathrm{cu}$. $\mathrm{ft}$. In addition, there is bunker capacity of $26,183 \mathrm{cu} . \mathrm{ft}$. 